\title{
Inhibiting APOBEC3 Activity with Single-Stranded DNA Containing 2'-Deoxyzebularine Analogues
}

\author{
Maksim V. Kvach, ${ }^{\dagger, \#}$ Fareeda M. Barzak, ${ }^{\dagger, \#}$ Stefan Harjes, ${ }^{\dagger, \# ~ H e n r y ~ A . ~ M . ~ S c h a r e s, ~}{ }^{\S, \#}$
}

Geoffrey B. Jameson, ${ }^{\dagger, \hbar}$ Alex M. Ayoub, ${ }^{\S}$ Ramkumar Moorthy, ${ }^{\S}$ Hideki Aihara, ${ }^{\| \odot ~ R e u b e n ~ S . ~ H a r r i s, ~}{ }^{\|, \perp}$

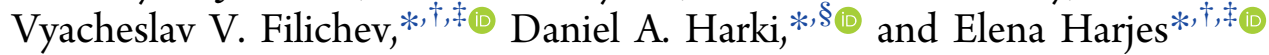

${ }^{\dagger}$ Institute of Fundamental Sciences, Massey University, Private Bag 11 222, Palmerston North 4442, New Zealand

${ }^{\ddagger}$ Maurice Wilkins Centre for Molecular Biodiscovery, Auckland 1142, New Zealand

${ }^{\S}$ Department of Medicinal Chemistry and "Department of Biochemistry, Molecular Biology, and Biophysics, University of Minnesota, Minneapolis, Minnesota 55455, United States

${ }^{\perp}$ Howard Hughes Medical Institute, University of Minnesota, Minneapolis, Minnesota 55455, United States

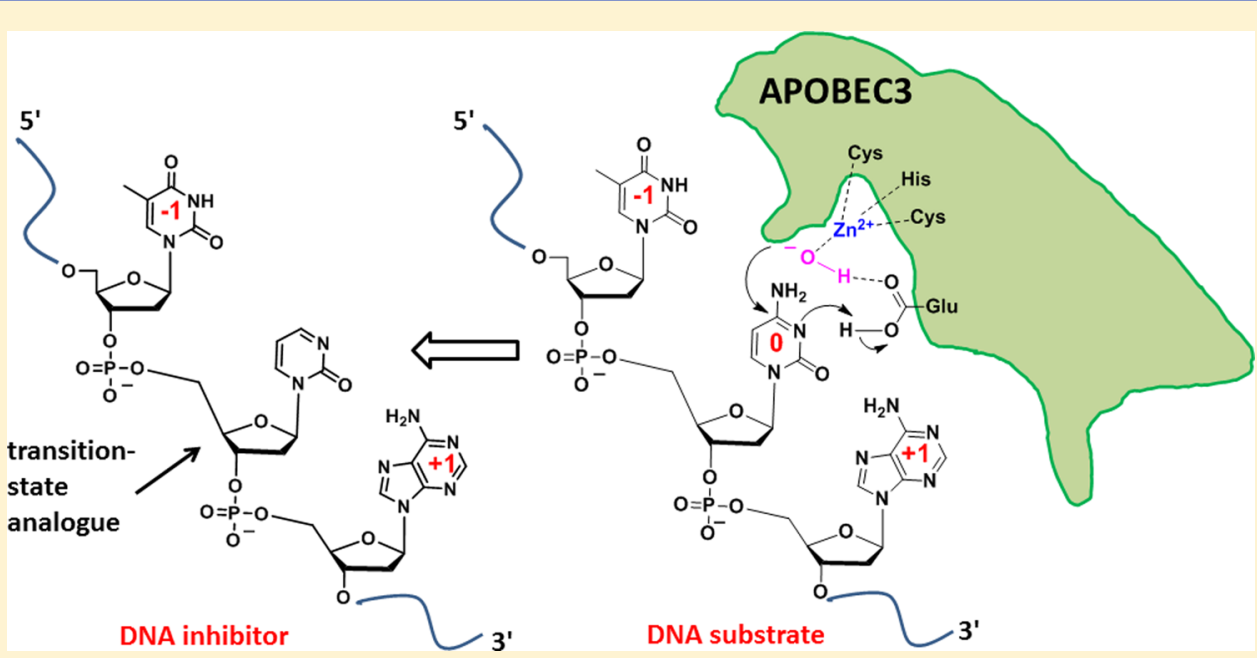

ABSTRACT: APOBEC3 enzymes form part of the innate immune system by deaminating cytosine to uracil in single-stranded DNA (ssDNA) and thereby preventing the spread of pathogenic genetic information. However, APOBEC mutagenesis is also exploited by viruses and cancer cells to increase rates of evolution, escape adaptive immune responses, and resist drugs. This raises the possibility of APOBEC3 inhibition as a strategy for augmenting existing antiviral and anticancer therapies. Here we show that, upon incorporation into short ssDNAs, the cytidine nucleoside analogue 2'-deoxyzebularine (dZ) becomes capable of inhibiting the catalytic activity of selected APOBEC variants derived from APOBEC3A, APOBEC3B, and APOBEC3G, supporting a mechanism in which ssDNA delivers $\mathrm{dZ}$ to the active site. Multiple experimental approaches, including isothermal titration calorimetry, fluorescence polarization, protein thermal shift, and nuclear magnetic resonance spectroscopy assays, demonstrate nanomolar dissociation constants and low micromolar inhibition constants. These dZ-containing ssDNAs constitute the first substrate-like APOBEC3 inhibitors and, together, comprise a platform for developing nucleic acid-based inhibitors with cellular activity.

$\mathrm{E}$ nzymes of the human APOBEC3 (A3A-H) family normally combat retroviruses and other pathogenic elements by deaminating 2'-deoxycytidine to 2'-deoxyuridine in singlestranded DNA (ssDNA) (Figure 1A). The combination of this deamination-dependent mechanism and a deaminationindependent mechanism, ${ }^{1}$ most likely dependent on nucleic acid binding, constitutes a potent block to parasite replication. Not surprisingly, viral pathogens have developed A3 counteraction strategies that range from active degradation (HIV-1 and related lentiviruses) $)^{1-4}$ to apparently passive avoidance (papilloma viruses and polyomaviruses). ${ }^{5,6}$ Moreover, the fact that many immune-escape and drug-resistance mutations occur within A3preferred di- and trinucleotide motifs ${ }^{7-10}$ strongly suggests that viruses have evolved mechanisms for both regulating and benefiting from $\mathrm{A} 3$ mutagenesis.

Special Issue: Regulating the Central Dogma

Received: August 13, 2018

Revised: October 19, 2018

Published: November 12, 2018 
A)



B)<smiles></smiles><smiles>O=C1NC(O)CCN1C1OC(O)C(O)C1O</smiles>

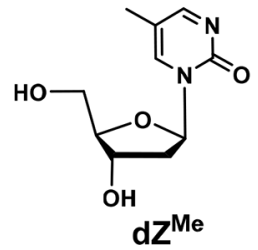

Figure 1. (A) Deamination of dC in ssDNA by A3 enzymes. (B) TSAs used in this work: zebularine, its $2^{\prime}$-deoxy analogue (dZ), 5-methyl-2'deoxyzebularine $\left(\mathrm{dZ} \mathrm{Me}^{\mathrm{Me}}\right)$, and tetrahydrouridine (THU).

A3 enzymes have intrinsic preferences for deaminating cytosine bases preceded by thymine $\left(5^{\prime}-\mathrm{TC}, \mathrm{A} 3 \mathrm{~A}-\mathrm{D}, \mathrm{A} 3 \mathrm{~F}\right.$, and $\mathrm{A} 3 \mathrm{H})$ or by another cytosine $\left(5^{\prime}-\mathrm{C} \underline{\mathrm{C}}, \mathrm{A} 3 \mathrm{G}\right) .{ }^{1{ }^{10-14}}$ The genomes of many different tumor types, including bladder, breast, cervix, head/neck, and lung, often have large fractions of mutations in $5^{\prime}$-TC motifs. ${ }^{15-1}{ }^{\prime}$ These $5^{\prime}$-TC-to-TT and 5'-TC-to-TG mutations are typically followed on the $3^{\prime}$-side by bases other than cytosine, that is, adenine, guanine, or thymine, thereby constituting an APOBEC mutation signature. A range of genetic, biochemical, and structural studies has combined to implicate $\mathrm{A} 3 \mathrm{~B}$ as the primary source of these mutations and $\mathrm{A} 3 \mathrm{~A}$ and $\mathrm{A} 3 \mathrm{H}$ as potential secondary sources (depending on patient genotype and tumor type). APOBEC mutagenesis has been shown to contribute to both clonal and subclonal mutational events, ${ }^{17,18}$ and its frequency often increases from primary to metastatic disease. ${ }^{16} \mathrm{~A} 3 \mathrm{~B}$ expression levels and APOBEC signature mutations also correlate with poor clinical outcomes, including disease recurrence, metastasis, and drug resistance..$^{15,19,20}$ These observations support a model in which APOBEC mutagenesis promotes tumor evolution and strongly influences disease trajectories. Therefore, chemical modulators of APOBEC activity may yield useful chemical probes for mechanistic studies and, possibly, therapeutic compounds to harness APOBEC mutagenesis. $^{21}$

The mechanism of cytosine deamination for APOBECs is thought to be similar to that for cytidine deaminase (CDA), an enzyme that processes individual nucleosides. ${ }^{22}$ The cytidine analogues zebularine $[\mathrm{Z}$ (Figure 1B)], 2'-deoxyzebularine (dZ), and tetrahydrouridine (THU) are known transition-state analogues (TSAs) of cytidine deaminase (CDA). ${ }^{23-25}$ These competitive inhibitors bind tightly to the active site of CDA, as indicated by crystal structures. ${ }^{23-28}$ Here we show that these TSAs as free nucleosides do not alter the activity of A3 enzymes (Figure S1), but micromolar-potent A3 inhibitors are obtained upon introduction of $\mathrm{dZ}$ in place of the target $2^{\prime}$-deoxycytidine in DNA substrates (dZ-ssDNA). These findings open new avenues for further investigations of interactions between active A3 enzymes and ssDNA and, importantly, for the rational design of competitive A3 inhibitors for use with living cells.

\section{MATERIALS AND METHODS}

Detailed methods are provided in the Supporting Information. Synthesis of 2'-Deoxyzebularine (dZ), Its Phosphoramidite, and Oligonucleotides Containing $\mathrm{dZ}$ and $\mathrm{dZ} \mathrm{Z}^{\mathrm{Me}}$. Synthetic procedures are provided in the Supporting Information.

Protein Expression and Purification. Human APOBEC3A (residues 1-199, Uniprot entry P31941) was cloned as the inactive E72A mutant with a $\mathrm{His}_{6} \mathrm{C}$-terminal fusion tag into an expression vector (pETite, Lucigen), expressed in Escherichia coli BL21 DE3 cells (Hi-Control, Lucigen), and purified as described previously. ${ }^{29}$

The A3B C-terminal domain (residues 187-378) was cloned into the $\mathrm{pET} 24 \mathrm{a}$ vector (Novagen) to produce $\mathrm{A}_{3} \mathrm{~B}_{\mathrm{CTD}}$ proteins with a noncleavable C-terminal $\mathrm{His}_{6}$ tag (LEHHHHHH) that were derived as previously described. ${ }^{30}$ Several derivative constructs previously reported ${ }^{31}$ were used in this study. $\mathrm{A} 3 \mathrm{~B}_{\mathrm{CTD}}-\mathrm{QM}-\Delta \mathrm{L} 3$ and $\mathrm{A} 3 \mathrm{~B}_{\mathrm{CTD}}-\mathrm{QM}-\Delta \mathrm{L} 3-\mathrm{E} 255 \mathrm{~A}$ were expressed in E. coli strain BL21(DE3) (Lucigen), and $\mathrm{A}_{3} \mathrm{~B}_{\mathrm{CTD}^{-}}$ QM- $\Delta$ L3-AL1swap was expressed in E. coli strain C41(DE3)pLysS (Lucigen). The E. coli culture was grown at $37^{\circ} \mathrm{C}$ in $\mathrm{LB}$ medium; once the mid log growth phase had been reached, the culture was supplemented with $100 \mu \mathrm{M}$ zinc chloride, before protein expression was induced by the addition of isopropyl $\beta$-D1-thiogalactopyranoside (IPTG) to a final concentration of 0.5 $\mathrm{mM}$ and overnight incubation at $18{ }^{\circ} \mathrm{C}$.

$\mathrm{A} 3 \mathrm{~B}_{\mathrm{CTD}}-\mathrm{DM}$ was expressed and purified as reported in ref 31 . A3 $\mathrm{G}_{\mathrm{CTD}}$ (residues 191-384, wt) was purified as described previously. ${ }^{32}$ The glutathione $S$-transferase (GST)-fused A3 $\mathrm{G}_{\mathrm{CTD}}$ was expressed in E. coli BL21(DE3) cells overnight at $17^{\circ} \mathrm{C}$. After being harvested, the cells were resuspended in 50 mM sodium phosphate buffer ( $\mathrm{pH} 7.4$ ) and lysed by sonication. After ultracentrifugation at $25000 \mathrm{~g}$ for $10 \mathrm{~min}$, the supernatant was added to glutathione (GSH)-Sepharose, which was subsequently washed. For kinetic analysis, the GST fusion protein was eluted from the Sepharose matrix with $100 \mathrm{mM}$ GSH in phosphate buffer. By using filtration at $4000 g$, the buffer was changed to a solution containing $75 \mathrm{mM}$ sodium phosphate and $75 \mathrm{mM}$ citrate ( $\mathrm{pH}$ 5.5).

Fluorescence Polarization Assay. Fluorescence polarization assays were performed with recombinant [purified from E. coli strain BL21(DE3)] A3A (amino acids 1-195, expressed using the pGEX vector as a GST fusion protein $)^{30}$ with the catalytic glutamic acid mutated to alanine (E72A) to render the enzyme unable to deaminate the substrate. The assay buffer consisted of 2-( $N$-morpholino)ethanesulfonic acid (MES; 50 $\mathrm{mM}$, aqueous), $\mathrm{NaCl}$ (100 $\mathrm{mM}$, aqueous), tris(2-carboxyethyl)phosphine (TCEP; $2 \mathrm{mM}$, aqueous), and 3-[(3cholamidopropyl)dimethylammonio]-1-propanesulfonate (CHAPS; $4 \mathrm{mM}$, aqueous) at $\mathrm{pH}$ 6.0. The $15 \mu \mathrm{M}$ stock solutions of fluorescent tracer 5'-(6-FAM)TTTTCAT (Integrated DNA Technologies; molecular weight of $2598.3 \mathrm{~g} / \mathrm{mol}$ ) in molecular biology grade water were diluted to $15 \mathrm{nM}$ in assay buffer. All FP experiments were performed with a $10 \mu \mathrm{L}$ assay volume in black round-bottom low-volume 384-well plates (Corning 4514). A direct binding experiment (Chart S3) was first performed to determine the $K_{\mathrm{d}}$ of 5'-(6-FAM)TTTTCAT-3' with A3A-E72A by serially diluting the protein $(1: 1,10 \mu \mathrm{M}$ starting concentration) and incubating with a constant concentration 
Scheme $1^{a}$

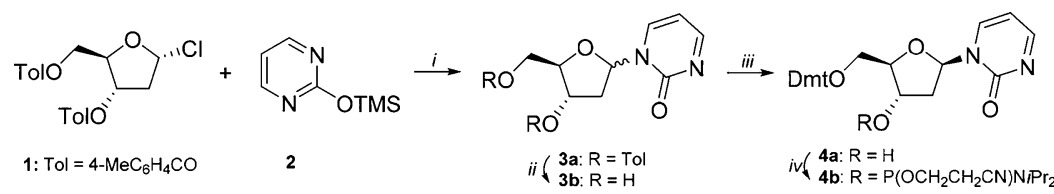

${ }^{a}$ Reagents and conditions: (i) $\mathrm{CHCl}_{3}$, distillation, $10 \mathrm{~min}, 54 \%, 12: 88 \alpha: \beta$ (3a); (ii) 28\% aqueous ammonia, $\mathrm{MeOH}, 48 \mathrm{~h}(3 \mathbf{b})$; (iii) 4,4'dimethoxytrityl chloride, pyridine, $0{ }^{\circ} \mathrm{C} \rightarrow$ room temperature, overnight, 54\% (4a); (iv) N,N-diisopropylamino-2-cyanoethoxychlorophosphine, $\mathrm{Et}_{3} \mathrm{~N}, \mathrm{CH}_{2} \mathrm{Cl}_{2}, 30 \mathrm{~min}, 88 \%(4 \mathbf{b})$.

$(15 \mathrm{nM})$ of the fluorescent tracer. Plates were incubated at room temperature for $30 \mathrm{~min}$, gently shaken for $1 \mathrm{~min}$, and then analyzed for fluorescence polarization on a BioTek Synergy 2 instrument (using standard instrument settings) with an excitation wavelength of $485(20) \mathrm{nm}$, an emission wavelength of $528(20) \mathrm{nm}$, and the top optics position at $510 \mathrm{~nm}$. The resulting anisotropy values were fit using the one-site binding (hyperbola) function in GraphPad Prism 7.0 to obtain the $K_{\mathrm{d}}$ of the fluorescent tracer. The directly measured $K_{\mathrm{d}}$ was $18.2 \pm 1.0$ $\mathrm{nM}$ (Chart S3). This value was used for all further calculations. Competition binding experiments were then performed with the prebound fluorescent tracer and various test ligands to quantify their binding affinities, as described in the Supporting Information.

Isothermal Titration Calorimetry (ITC). Desalted unmodified DNA oligonucleotides were purchased (Integrated DNA Technologies) at 1 or $5 \mu \mathrm{mol}$ synthesis scale and dissolved in one of the buffers described below to give $10 \mathrm{mM}$ solutions. ITC experiments were conducted at $25{ }^{\circ} \mathrm{C}$ using a Micro-Cal ITC200 (now Malvern Instruments) isothermal titration calorimeter. A3A-E72A (130 $\mu \mathrm{M}$ in high-salt or medium-salt buffer) or $\mathrm{A}_{3} \mathrm{~B}_{\mathrm{CTD}}-\mathrm{QM}-\Delta \mathrm{L} 3-\mathrm{AL} 1 \mathrm{swap}(100 \mu \mathrm{M}$, activity assay buffer) was titrated in the corresponding buffer. DNA oligonucleotides at $1.6 \mathrm{mM}$ (for A3A-E72A) or $300 \mu \mathrm{M}$ (for $\mathrm{A} 3 \mathrm{~B}_{\mathrm{CTD}}$-QM- $\Delta \mathrm{L} 3-\mathrm{AL} 1$ swap) were added in 18 steps of $2.0 \mu \mathrm{L}$ each (plus a first addition with decreased volume of $0.4 \mu \mathrm{L}$ to prevent dilution of the DNA in the syringe due to the long wait before the start of the experiment). Oligos and the enzymes were dialyzed against the appropriate buffer. For A3A-E72A, the highsalt buffer consisted of $25 \mathrm{mM}$ sodium phosphate, $500 \mathrm{mM}$ $\mathrm{NaCl}, 300 \mathrm{mM}$ choline acetate, $5 \mathrm{mM} \beta$-mercaptoethanol, and $0.2 \mathrm{mM} \mathrm{Na}_{2}$-EDTA ( $\mathrm{pH}$ 6.0) and the medium-salt buffer consisted of $50 \mathrm{mM}$ MES, $100 \mathrm{mM} \mathrm{NaCl}$, and $2.0 \mathrm{mM}$ tris (2carboxyethyl)phosphine ( $\mathrm{pH}$ 6.0). For $\mathrm{A} 3 \mathrm{~B}_{\mathrm{CTD}} \mathrm{QM}-\Delta \mathrm{L} 3-$ AL1swap, the activity assay buffer consisted of $50 \mathrm{mM}$ citratephosphate buffer, $200 \mathrm{mM} \mathrm{NaCl}$, and $2 \mathrm{mM} \beta$-mercaptoethanol (pH 5.5).

Thermal Shift Assay. A fluorescence-based thermal shift assay was used to assess the capability of ssDNA oligonucleotides to bind $\mathrm{A}_{3} \mathrm{~B}_{\mathrm{CTD}}$ proteins, through examination of changes in the thermal stability of the proteins. Binding assays were conducted using $A 3 B_{C T D}$ protein constructs, $A 3 B_{C T D}-Q M-\Delta L 3$ and $A 3 B_{C T D}-Q M-\Delta L 3-E 255 A$, where the over the time of the experiment there was insignificant conversion of $\mathrm{dC}$ to $\mathrm{dU}$ by the very weakly active $A 3 B_{C T D}-Q M-\Delta L 3$ and none by the inactive mutant $A 3 B_{C T D}-Q M-\Delta L 3-E 255 A$ to determine if differences in binding affinity occur due to a single amino acid change (E255A) in the protein. Purified $\mathrm{A}_{3} \mathrm{~B}_{\mathrm{CTD}}$ protein was appropriately diluted in buffer [ $50 \mathrm{mM}$ citrate-phosphate $(\mathrm{pH}$

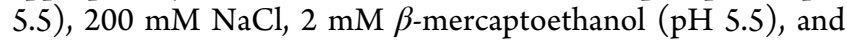
$200 \mu \mathrm{M}$ 4,4-dimethyl-4-silapentane-1-sulfonic acid (DSS)]. Assay experiments were set up in a total volume of $25 \mu \mathrm{L}$ containing $20 \mu \mathrm{M} \mathrm{A}_{3} \mathrm{~B}_{\mathrm{CTD}}$ protein and $100 \mu \mathrm{M}$ ssDNA oligonucleotide, mixed with SYPRO Orange dye (Bio-Rad) at a final concentration of $10 \times$. Assays were dispensed into wells of a white low-profile 96-well plate (Roche), sealed with an optical seal, shaken, and centrifuged. Thermal scanning (from 20 to 95 ${ }^{\circ} \mathrm{C}$ at a rate of $0.6{ }^{\circ} \mathrm{C} / \mathrm{min}$ ) was performed using a real-time polymerase chain reaction setup on a LightCycler 480 instrument II (Roche) with fluorescence emission spectra recorded with combinations of excitation and emission filters (483-610 and 483-568 nm, respectively).

Evaluation of Nucleosides by a Fluorescence-Based Deamination Assay Using $\mathrm{hA} 3 \mathrm{~A}$ and $\mathrm{hA} 3 \mathrm{~B}_{\text {СтD }}$ Expressed in HEK293T Cells. A3-deaminase activity assays were performed according to the method described by $\mathrm{Li}$ and colleagues $^{33}$ with the following modifications. Stock solutions of nucleosides in molecular biology grade water were serially diluted in protein dilution buffer $(10 \mu \mathrm{L})$. Recombinant (purified from HEK293T cells) full length A3A-mycHis ${ }^{33}$ (10 ng) or C-terminal domain (amino acids 195-382) $\mathrm{A}^{3 B_{\mathrm{CTD}^{-}}}$ mycHis $^{34,35}(25 \mathrm{ng})$ proteins were delivered to each well in protein dilution buffer $(10 \mu \mathrm{L})$. The deamination dualfluorophoric substrate oligo 5'-(6-FAM)-AAA-TAT-CCCAAA-GAG-AGA-(TAMRA) (2 pmol) and UDG (25 units) were delivered in TE buffer $(10 \mu \mathrm{L})$. Cleavage of oligonucleotides containing an abasic site using $\mathrm{NaOH}(4 \mathrm{M}, 3 \mu \mathrm{L})$ occurred after incubation of the reaction mixture at $37^{\circ} \mathrm{C}$ for 30 min. Plates were read using a BioTek Synergy $\mathrm{H} 1$ plate reader with an excitation wavelength at $490 \mathrm{~nm}$ and emission at 520 $\mathrm{nm}$. Each experiment was performed in biological duplicates with three technical replicates per condition. The resulting total fluorescence values were reported together with the no-protein low control and protein only high control (no inhibitors). Nonspecific inhibitor $\mathrm{MN}-1$ was used as a positive control (Figure S1). ${ }^{33}$

Evaluation of Inhibitors in a Nuclear Magnetic Resonance (NMR)-Based Assay. The Supporting Information provides details about the experiments and how inhibition constants were calculated.

\section{RESULTS}

Methodology of This Investigation. First, we confirmed that pyrimidine-based TSA nucleosides (Figure 1B) do not inhibit A3 enzymes (Figure S1). Because ssDNA is the preferred substrate of $\mathrm{A} 3$ proteins, we decided to evaluate the inhibitory effect of chemically modified ssDNAs in which the target $2^{\prime}$ deoxycytidine in the recognition sequence ${ }^{32,36}$ is substituted with TSAs. We focused on $2^{\prime}$-deoxyzebularine $(\mathrm{dZ})$, as it is a known, stable, moderately potent TSA inhibitor of CDA with an apparent $K_{\mathrm{i}}$ of $2.9 \mu \mathrm{M}^{37}$ and its incorporation into DNA by automated synthesis is feasible. ${ }^{38}$ The quantity of modified oligos needed for the planned experiments warranted development of a new synthesis procedure for $\mathrm{dZ}$. Then, we investigated 
Table 1. Oligo Concentrations when the Fluorescence Anisotropy Decreased to the Half-Maximum Level ( $\left(\mathrm{C}_{50}\right)$ and Indirectly Measured Dissociation Constants $\left(K_{d}{ }^{\mathrm{FP}}\right)$ of ssDNA from A3A-E72A Obtained during Fluorescence Polarization (FP) Experiments in a Medium-Salt Buffer ${ }^{a}$

$\begin{array}{llcc} & \text { DNA sequence }\left(5^{\prime}-3^{\prime}\right) & \mathrm{IC}_{50}(\mu \mathrm{M}) & K_{\mathrm{d}}^{\mathrm{FP}}(\mu \mathrm{M}) \\ \text { Oligo-3*c } & \text { ATTCCCAATT } & 0.0550 \pm 0.0011 & 0.007 \pm 0.001 \\ \text { Oligo-4* } & \text { TTCCC } & 5.6 \pm 0.8 & 0.68 \pm 0.11 \\ \text { Oligo-5* } & \text { CCCAA } & 1.8 \pm 0.10 & 0.22 \pm 0.02 \\ \text { Oligo-10* } & \text { TTTTCAT } & 0.2800 \pm 0.0016 & 0.034 \pm 0.002 \\ \text { Oligo-11 } & \text { TTTTdUAT } & 15.0 \pm 1.9 & 1.8 \pm 0.3 \\ \text { Oligo-12 } & \text { TTTTCATTTT } & 0.0960 \pm 0.0012 & 0.012 \pm 0.001 \\ \text { Oligo-13 } & \text { AAAAATTCAAAGA } & 0.120 \pm 0.004 & 0.015 \pm 0.001 \\ \text { Oligo-14 } & \text { TTCAAAAA } & 0.1400 \pm 0.0022 & 0.017 \pm 0.001 \\ \text { Oligo-15 } & \text { TTTTdZAT } & 2.40 \pm 0.10 & 0.29 \pm 0.02\end{array}$

${ }^{a}$ Values shown are means \pm SEM (standard error of the mean). $\mathrm{IC}_{50}$ values were converted to $K_{\mathrm{d}}{ }^{\mathrm{FP}}$ values using the Kenakin equation (see the Supporting Information) with appropriate error propagation. ${ }^{b} \mathrm{dU}$ is $2^{\prime}$-deoxyuridine. ${ }^{c} \mathrm{An}$ asterisk denotes an oligo evaluated in both ITC and FP experiments.

Table 2. Dissociation Constants $\left(K_{\mathrm{d}}^{\mathrm{ITC}}\right)$ of ssDNA from A3 Enzymes Obtained by Isothermal Titration Calorimetry in Different Buffers $^{a}$

\begin{tabular}{|c|c|c|c|c|}
\hline & DNA sequence $\left(5^{\prime}-3^{\prime}\right)$ & buffer & enzyme & $K_{\mathrm{d}}^{\mathrm{ITC}}(\mu \mathrm{M})$ \\
\hline \multirow[t]{2}{*}{ Oligo-1 } & AAAAAAAATTCAAAAAAAAA & high-salt & A3A-E72A & $24 \pm 7$ \\
\hline & & medium-salt & A3A-E72A & $0.11 \pm 0.05$ \\
\hline \multirow[t]{2}{*}{ Oligo-2 } & ATTTCATTT & high-salt & A3A-E72A & $25.3 \pm 0.9$ \\
\hline & & medium-salt & A3A-E72A & $0.20 \pm 0.04$ \\
\hline Oligo- $3^{* b}$ & АTTCССАATT & medium-salt & A3A-E72A & $0.24 \pm 0.10$ \\
\hline Oligo-4* & TTCCC & medium-salt & A3A-E72A & $5.0 \pm 0.4$ \\
\hline Oligo-6 & TTCAT & medium-salt & A3A-E72A & $0.48 \pm 0.10$ \\
\hline Oligo-7 & ATTCCdZAATT & medium-salt & A3A-E72A & $0.97 \pm 0.15$ \\
\hline Oligo-8 & ATTCCdZ ${ }^{\mathrm{Me}} \mathrm{AATT}$ & medium-salt & A3A-E72A & $1.7 \pm 0.3$ \\
\hline Oligo-9 & ATTTdZATTT & activity assay & A3Bc-QM- $\Delta$ L3-AL1swap & $5.5 \pm 0.6$ \\
\hline Oligo-10* & TTTTCAT & med. salt & A3A-E72A & $0.27 \pm 0.04$ \\
\hline Oligo-16 & 5'-(6-FAM)TTT TCAT & med. salt & A3A-E72A & $0.41 \pm 0.04$ \\
\hline
\end{tabular}

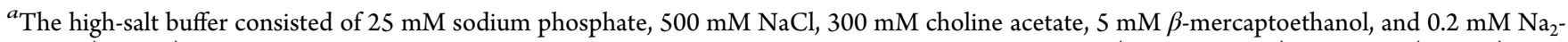
EDTA (pH 6.0). The medium-salt buffer consisted of $50 \mathrm{mM} \mathrm{MES,} 100 \mathrm{mM} \mathrm{NaCl}$, and $2.0 \mathrm{mM}$ tris(2-carboxyethyl)phosphine (pH 6.0). The activity assay buffer consisted of $50 \mathrm{mM}$ citrate-phosphate buffer, $200 \mathrm{mM} \mathrm{NaCl}$, and $2 \mathrm{mM} \beta$-mercaptoethanol (pH 5.5). Means \pm the standard deviation (SD) are shown. Uncertainties (SD) in $K_{\mathrm{d}}^{\text {ITC }}$ were calculated using standard error propagation methods from partial derivatives. ${ }^{b}$ An asterisk denotes an oligo evaluated in both ITC and FP experiments. A3A prefers to deaminate the third C in the CCC motif. ${ }^{36}$

the binding affinity and inhibitory activity of selected modified oligos. Binding data were recorded using a combination of fluorescence polarization (FP), ITC, and thermal shift assays. We confirmed that 9-10 nucleotides is a good compromise between the length of the oligo and binding affinity and concluded that binding of TSA-containing oligos must be investigated with catalytically active proteins. Finally, our activity data show clearly the inhibition of selected $\mathrm{A} 3$ variants by $\mathrm{dZ}$-containing oligos. The list of proteins used can be found in Figure S3, and the sequences of oligos in Tables 1 and 2. One should note that the preferred A3G substrate motif is CCEA (underlined $\mathrm{C}$ preferentially deaminated), whereas A3A and A3B prefer the TCA motif but can also readily deaminate the CCCA motif. The rationale for the design of each oligo can be found in Table S3.

A3 Activity Is Unaffected by Free Nucleoside Transition-State Analogues. Human $\mathrm{A} 3 \mathrm{~A}$ and the catalytic Cterminal domain of $\mathrm{A} 3 \mathrm{~B}\left(\mathrm{~A} 3 \mathrm{~B}_{\mathrm{C}}\right.$ ) $)$ were purified from human $293 \mathrm{~T}$ cells ( $\left.\mathrm{hA} 3 \mathrm{~A}, \mathrm{hA} 3 \mathrm{~B}_{\text {СтD }}\right)^{33}$ and tested using a fluorescencebased activity assay ${ }^{33}$ (for details, see Materials and Methods and the Supporting Information) for inhibition by nucleosides $\mathrm{THU}, \mathrm{Z}$, and $\mathrm{dZ}$. The nonspecific small molecule inhibitor MN$1^{33}$ almost completely abolished the activity of enzymes used in the assay ( $\mathrm{hA} 3 \mathrm{~A}, \mathrm{hA} 3 \mathrm{~B}_{\mathrm{CTD}}$, and UDG). In contrast, THU, $\mathrm{Z}$, and $\mathrm{dZ}$ did not affect the deamination of ssDNA by these enzymes, even at the high concentration of $2 \mathrm{mM}$ (Figure S1). These results are consistent with earlier observations of no or very weak binding of A3 proteins to individual nucleotides and barely detectable deamination of 2 '-deoxycytidine. ${ }^{39,40}$

Synthesis of dZ-Containing ssDNA. We developed a new straightforward procedure for preparing $\mathrm{dZ}$ phosphoramidite for incorporation into ssDNA based on the classical silyl modification of the Hilbert-Johnson reaction (Scheme 1 and the Supporting Information). This synthesis, which is free of Lewis acids and requires no workup, leads straightforwardly to product 3a, which was purified by flash chromatography. We obtained a ratio and yield of the desired $\beta$ anomer $(88: 12 \beta: \alpha)$ much higher than those determined by the previously published procedure. ${ }^{38,41} \mathrm{dZ}$ was further used in the synthesis of modified 2 '-oligodeoxynucleotides (Oligos) as described in the Supporting Information. Commercially available phosphoramidite of 5methyl-2'-deoxyzebularine was used in the synthesis of $\mathrm{dZ}^{\mathrm{Me}}$ containing oligos.

Binding of Modified and Unmodified ssDNAs to A3 Proteins. We tested how the introduction of $\mathrm{dZ}$ and its 5methyl derivative, $\mathrm{dZ}^{\mathrm{Me}}$, affected the affinity of ssDNA for the $\mathrm{A} 3$ 
enzymes, in particular $\mathrm{A} 3 \mathrm{~A}$ and the catalytically competent $\mathrm{A} 3 \mathrm{~B}_{\mathrm{CTD}}$ and selected mutants, to probe the generality of zebularine analogues as inhibitors of A3 proteins. Given that different A3 proteins ${ }^{13,36}$ have varying preferences for nucleobases surrounding the target cytosine, the sequences surrounding the zebularine moiety were chosen to match the preferred ssDNA recognition motif. To study A3-ssDNA binding, we used the inactive A3A-E72A mutant, where the active-site glutamic acid is replaced with alanine, to avoid complications of deamination reactions occurring when the ligand contained cytosine. The E72A mutation does not change the geometry of the active site, as water was observed in the crystal structure instead of the glutamate side chain. ${ }^{42}$ As A3A is a highly active enzyme with the highest affinity for DNA among human A3 catalytically active domains, ${ }^{29,36}$ it is best suited for binding assays. Two methods widely applied for binding characterization were used: fluorescence polarization (FP) and isothermal titration calorimetry (ITC), which yield the indirectly determined dissociation constant $K_{\mathrm{d}}^{\mathrm{FP}}$ [sometimes termed $K_{\mathrm{i}}$ (see the Supporting Information) $]^{43-45}$ and the directly measured dissociation constant $K_{d}^{\text {ITC }}$, respectively.

FP measurements were taken in competitive mode, where unlabeled ssDNA competed with the fluorescently labeled ssDNA for the protein (Figure S2). This results in dissociation constants $K_{\mathrm{d}}^{\mathrm{FP}}$ (Table 1) that should be directly comparable with $K_{\mathrm{d}}^{\text {ITC }}$, assuming that the binding of the unlabeled ssDNA and the binding of fluorescently labeled ssDNA to the protein are identical. As a positive control, $K_{\mathrm{d}}{ }^{\mathrm{FP}}$ for the nonlabeled ssDNA (Oligo-10) was $34 \pm 2 \mathrm{nM}$ compared to the directly measured value of $19 \pm 2 \mathrm{nM}$ for titration of the fluorescently tagged Oligo-10. The differences between the two values are likely attributable to the experimental conditions (competitive displacement with a nonlabeled oligo vs direct binding with a fluorescently labeled oligo). Weaker binding of ssDNA containing dU (Oligo- $\left.11 ; K_{\mathrm{d}}^{\mathrm{FP}}=1800 \pm 300 \mathrm{nM}\right)$, as a negative control, compared to $\mathrm{dC}$ is in accord with published data ${ }^{29,46,47}$ and highlights the binding specificity. The dZ-modified DNA had an affinity for A3A-E72A lower than that of the dCcontaining substrate [for Oligo-15, $K_{\mathrm{d}}{ }^{\mathrm{FP}}=290 \pm 20 \mathrm{nM}$; for Oligo-10, $K_{\mathrm{d}}{ }^{\mathrm{FP}}=34 \pm 2 \mathrm{nM}$ (Table 1 and vide subra)]. The affinity of the dZ-modified DNA was still substantially higher than that of the dU-containing ssDNA that mimics the product of deamination [Oligo-15 vs Oligo-11 (Table 1)]. The comparison of Oligo-10, -12, -13, and -14 shows some increase in binding affinity with a length from seven to ten nucleotides and no further increase in binding affinity up to 13 nucleotides (Oligo-13).

ITC experiments ${ }^{29}$ (Table 2) were initially performed in a high-salt buffer ( $800 \mathrm{mM}$ ionic strength), which was necessary for sample stability over the multiday, multidimensional NMR measurements. ${ }^{29}$ For Oligo-1 $\left(20-\right.$ mer, $\left.\mathrm{A}_{8} \mathrm{~T}_{2} \mathrm{CA}_{9}\right)$ and the much shorter Oligo-2 (9-mer, $\mathrm{AT}_{3} \mathrm{CAT}_{3}$ ) with a different sequence, very similar dissociation constants $\left(K_{\mathrm{d}}^{\mathrm{ITC}}\right)$ of $24 \pm 7$ and $25 \pm 1$ $\mu \mathrm{M}$, respectively, were obtained (Table 2 ), the former value being the same as that reported previously. ${ }^{29}$ Given the very marked differences from the FP dissociation constants, further studies proceeded in buffer with a lower salt concentration (medium buffer, $150 \mathrm{mM}$ ionic strength), comparable to that for FP measurements. The new $K_{d}^{\text {ITC }}$ values obtained for Oligo-1 and Oligo-2 were more than 100 times lower than values measured in the high-salt buffer (Table 2). Moreover, differences in binding were now evident, such that the 20-mer bound nearly twice as strongly $\left(K_{\mathrm{d}}^{\mathrm{ITC}}=0.11 \pm 0.05 \mu \mathrm{M}\right)$ as the 9-mer $\left(K_{\mathrm{d}}^{\mathrm{ITC}}=0.20 \pm 0.04 \mu \mathrm{M}\right)$. Further shortening of the DNA sequence to five nucleotides resulted in a decreased affinity for the protein (Oligo-4, -5 , and -6 compared to Oligo- 3 in Table 2), showing that binding affinity increases with oligo length and confirming that a length of $\sim 9-10$ nucleotides is a good compromise between the length of the oligo and binding affinity. This length is used here and was used previously in NMR activity assays. $^{32,48}$

In general, $K_{\mathrm{d}}{ }^{\mathrm{FP}}$ values were somewhat lower than $K_{\mathrm{d}}^{\mathrm{ITC}}$ values (Tables 1 and 2), which can likely be attributed to differences in experimental conditions: competition binding studies for $K_{d}{ }^{F P}$ versus direct binding experiments for $K_{d}$ ITC . Additionally, the different concentrations of assay components used may contribute to different oligomeric states of the protein, thereby affecting the measured binding affinities. The oligomeric state of A3A-E72A under these conditions warrants further investigation. Nonetheless, consistent trends were observed between these two biophysical methods. Shortening of the oligo resulted in a reduced level of binding to A3A-E72A in both methods [Oligo-4 and -5 vs Oligo-3 (Tables 1 and 2)], consistent with the published data. ${ }^{47}$ In parallel with FP results and despite the different oligo sequences that were used, introduction of $\mathrm{dZ}$ into the ssDNA sequence (for Oligo-7, $K_{d}^{\text {ITC }}=0.97 \pm 0.15 \mu \mathrm{M}$ ) resulted in weaker binding, relative to that of the corresponding cytidine-containing ssDNA (for Oligo-3, $K_{\mathrm{d}}^{\mathrm{ITC}}=0.24 \pm 0.10$ $\mu \mathrm{M})$; specifically, 8.5- and 4-fold increases in $K_{\mathrm{d}}^{\mathrm{FP}}$ and $K_{\mathrm{d}}^{\text {ITC }}$, respectively, were observed (Table 2). The addition of a 5methyl substituent to $\mathrm{dZ}\left(\mathrm{dZ}{ }^{\mathrm{Me}}\right)$, Oligo-8, had a negligible effect on binding relative to that of unmethylated Oligo-7 (Table 2). This impaired binding of transition-state analogues, $\mathrm{dZ}$ - or $\mathrm{dZ}^{\mathrm{Me}}$-ssDNA, to the E72A mutant, compared to substrate, is consistent with Glu72 being a critical residue in the formation of the transition state for active A3 enzymes.

To test the importance of the catalytic glutamate (Glu72 in $\mathrm{A} 3 \mathrm{~A}$ ), we evaluated binding of ssDNAs to two protein constructs of the catalytically active C-terminal domain of mutant $\mathrm{A} 3 \mathrm{~B}, \mathrm{~A} 3 \mathrm{~B}_{\mathrm{CTD}}-\mathrm{QM}-\Delta \mathrm{L} 3$ [quadruple mutant with loop 3 removed (Figure $\mathrm{S} 3$ )] and its catalytically inactive derivative, $\mathrm{A} 3 \mathrm{~B}_{\mathrm{CTD}}-\mathrm{QM}-\Delta \mathrm{L} 3-\mathrm{E} 255 \mathrm{~A} .^{30}$ For this experiment, we cannot use active $\mathrm{A} 3 \mathrm{~A}$, the most potent $\mathrm{A} 3$ deaminase, ${ }^{36}$ as it will fully deaminate the substrate during the experiment. The $\mathrm{A}_{3} \mathrm{~B}_{\mathrm{CTD}^{-}}$ QM- $\Delta$ L3 enzyme has the essential glutamic acid in the active site but because of the removal of loop 3 is only very weakly active in vitro: ${ }^{31}$ low conversion of the substrate to the product was detected by ${ }^{1} \mathrm{H}$ NMR spectroscopy only after incubation overnight (Figure S4). The interaction of TSA with the active site is not likely to be affected by the deletion of loop 3 from these proteins, as the loss of deaminase activity and associated binding affinity is due to effects outside of the active site. Deaminase activity can be restored by swapping loop 1 of $\mathrm{A} 3 \mathrm{~B}_{\mathrm{CTD}}-\mathrm{QM}-\Delta \mathrm{L} 3$ with loop 1 of $\mathrm{A} 3 \mathrm{~A}$, yielding the active $\mathrm{A} 3 \mathrm{~B}_{\mathrm{CTD}}$-QM- $\Delta$ L3-AL1swap enzyme. ${ }^{31}$ On the other hand, in the $\mathrm{A} 3 \mathrm{~B}_{\mathrm{CTD}}-\mathrm{QM}-\Delta \mathrm{L} 3-\mathrm{E} 255 \mathrm{~A}$ mutant the active-site glutamic acid (equivalent to Glu72 in A3A) is replaced with alanine. Therefore, these proteins provide a unique pair for evaluating the importance of the catalytic glutamate for binding of $\mathrm{dZ}$ containing oligos.

No binding of ssDNA to $A 3 B_{C T D}-Q M-\Delta L 3$ was seen by ITC under our standard conditions $[50 \mathrm{mM}$ citrate-phosphate buffer, $200 \mathrm{mM} \mathrm{NaCl}$, and $2 \mathrm{mM} \beta$-mercaptoethanol ( $\mathrm{pH} \mathrm{5.5)],}$ consistent with this mutant's very low deaminase activity. Moreover, for a weak binding event such as this to be studied by ITC, the required concentration of the protein would be in the 
high micromolar range, which is prohibitive because $\mathrm{A} 3$ proteins tend to precipitate from solution at this concentration. ${ }^{49}$ Consequently, we decided to use our previously published thermal shift assay, ${ }^{29}$ in which high ligand concentrations are used to enhance complex formation (Figure 2). ${ }^{50}$ Protein

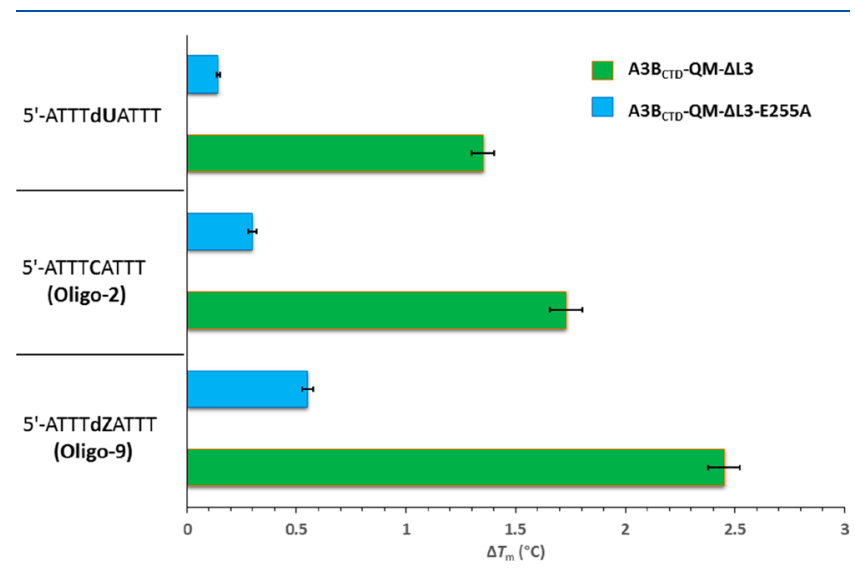

Figure 2. Results of thermal shift assay for $A 3 B_{\text {CTD- }} \mathrm{QM}-\Delta \mathrm{L} 3$ (green) and $\mathrm{A} 3 \mathrm{~B}_{\mathrm{CTD}}-\mathrm{QM}-\Delta \mathrm{L} 3-\mathrm{E} 255 \mathrm{~A}$ (blue) in the presence of the product of deamination ( $5^{\prime}$-dATTTdUATTT), substrate ( $5^{\prime}$-dATTTCAATTT), and dZ-containing Oligo-9 (dATTTdZATTT). The concentration of proteins was $20 \mu \mathrm{M}$, and the concentration of oligos was $100 \mu \mathrm{M}$ in the buffer: $50 \mathrm{mM}$ citrate-phosphate ( $\mathrm{pH} 5.5$ ), $200 \mathrm{mM} \mathrm{NaCl}, 2 \mathrm{mM} \beta$ mercaptoethanol ( $\mathrm{pH} 5.5$ ), and $200 \mu \mathrm{M}$ 4,4-dimethyl-4-silapentane-1sulfonic acid (DSS). Confidence intervals (95\%) are shown as error bars.

unfolding as the temperature increases is reported by the increased fluorescence of the nonpolar dye SYPRO Orange, which binds to hydrophobic patches exposed upon thermal denaturation. Usually, a higher thermal stability is associated with the strong binding of the ligand, in our case ssDNA, to the protein. We observed that the level of binding of oligos to inactive $A 3 B_{C T D}-Q M-\Delta L 3-E 255 A$ is significantly lower than to weakly active $A 3 B_{C T D}-Q M-\Delta L 3$, which retains the catalytic glutamic acid. Moreover, for $\mathrm{A}_{3} \mathrm{~B}_{\mathrm{CTD}}-\mathrm{QM}-\Delta \mathrm{L} 3$, the $\Delta T_{\mathrm{m}}$ value for $\mathrm{dZ}$-containing Oligo-9 is $0.72 \pm 0.10{ }^{\circ} \mathrm{C}$ higher than that for the substrate containing $\mathrm{dC}$ (in Figure 2, see the 95\% confidence interval), which is the expected result for an ssDNA that bears a TSA instead of dC. For the binding of inactivated $A 3 B_{\text {CтD }}-Q M-$ $\triangle \mathrm{L} 3-\mathrm{E} 255 \mathrm{~A}$ to different DNA oligos, the binding of $\mathrm{dZ}$ oligo cannot be distinguished from binding of the substrate, illustrating the importance of the active-site glutamate for binding of transition-state analogues.

Altogether, these results demonstrate that the choice of buffer, especially the ionic strength, affects strongly, by several orders of magnitude, the affinity of ssDNA for the A3 proteins. Moreover, binding of inactive protein to ssDNA-containing TSA is not a reliable predictor of inhibitory potential of these oligonucleotides. Therefore, we decided to use our previously described NMR-based activity assay ${ }^{32}$ to assess directly the inhibition of substrate deamination in fully active A3 enzymes by ssDNAcontaining TSAs.

2'-Deoxyzebularine Incorporated into ssDNA Is a Micromolar Inhibitor of A3 Enzymes. The MichaelisMenten constants for the enzymes and their mutants used in this study (described in the Supporting Information), along with their ssDNA substrates, are summarized in Table 3. The behavior of $\mathrm{A}_{3} \mathrm{~B}_{\mathrm{CTD}}-\mathrm{QM}-\Delta \mathrm{L} 3-\mathrm{AL} 1$ swap $^{30}$ (see a description of the enzyme in Figure S3), which has loop 1 of A3A transplanted
Table 3. Michaelis-Menten Constants for Selected A3 Enzymes and Mutants Measured by the NMR Assay ${ }^{32,40}$

\begin{tabular}{lllll}
\multicolumn{1}{c}{ protein } & substrate & \multicolumn{1}{c}{$k_{\text {cat }}\left(\mathrm{s}^{-1}\right)$} & \multicolumn{1}{c}{$K_{\mathrm{m}}(\mu \mathrm{M})$} & $\left(\mathrm{k}_{\mathrm{cat}} / \mathrm{K}_{\mathrm{m}}\right.$ \\
$\left.\mathrm{M}^{-1}\right)$
\end{tabular}

into $\mathrm{A} 3 \mathrm{~B}_{\mathrm{CTD}}$, was intermediate between previously reported activities for $A 3 A^{40}$ and $A 3 G_{C T D}{ }^{32}$ consistent with the previously reported data. ${ }^{36}$ However, the $k_{\text {cat }}$ of $\mathrm{A}_{3} \mathrm{~B}_{\mathrm{CTD}}-\mathrm{DM}$ [DM, double mutant (see Figure S3)] was anomalously low $\left[0.008 \pm 0.001 \mathrm{~s}^{-1}\right.$ compared to $0.10 \pm 0.04 \mathrm{~s}^{-1}$ for $\mathrm{A} 3 \mathrm{G}_{\mathrm{CTD}}{ }^{32}$ (Table 3)]. Residual enzyme activity in the presence of $\mathrm{dZ}$ ssDNA inhibitors was monitored directly by our NMR method. $^{32,48}$

Only the use of $\mathrm{dZ}$ instead of $\mathrm{dC}$ in the preferred $\mathrm{A} 3 \mathrm{G}_{\mathrm{CTD}}$ substrate [Oligo-7 versus Oligo-9 (Figure 3A,B)] conferred significant inhibition of $A 3 G_{C T D}$ deaminase activity. $d Z^{\mathrm{Me}}$ ssDNA (Oligo-8) had a marginal effect on the conversion of the preferred $A 3 \mathrm{G}_{\mathrm{CTD}}$ substrate $\left(\mathrm{AT}_{2} \mathrm{C}_{3} \mathrm{~A}_{2} \mathrm{~T}_{2}\right.$, Oligo-3) (Figure $3 \mathrm{~A}$ ). These data are consistent with 5-Me-cytidine being a much poorer substrate than cytidine for A3 proteins, with the exception of $\mathrm{A} 3 \mathrm{H} .{ }^{51-53}$ Therefore, for further investigations, we focused on the evaluation of dZ-containing oligos. For both $\mathrm{A} 3 \mathrm{~B}_{\mathrm{CTD}}-\mathrm{QM}-\Delta \mathrm{L} 3-\mathrm{AL} 1$ swap and $\mathrm{A} 3 \mathrm{~B}_{\mathrm{CTD}}-\mathrm{DM}$ (Figure 3 and the Supporting Information), using preferred substrate $5^{\prime}$ $\mathrm{AT}_{3} \mathrm{CAT}_{3}$ (Oligo-2), significant inhibition was observed with dZ-ssDNA [Oligo-9 (Figure 3C,D)]. The linear dependence of inverse deamination speed on inhibitor concentration was analyzed as described in the Supporting Information, assuming competitive inhibition, yielding micromolar inhibition constants $\left(K_{\mathrm{i}}\right)$ (Figure $3 \mathrm{~B}-\mathrm{D}$ ). In particular, for $\mathrm{A} 3 \mathrm{~B}_{\mathrm{CTD}}-\mathrm{QM}-\Delta \mathrm{L} 3-$ AL1swap, the $K_{\mathrm{i}}$ and $K_{\mathrm{d}}{ }^{\mathrm{ITC}}$ for Oligo-9 are very similar, $7.5 \pm 1.7$ and $5.5 \pm 0.6 \mu \mathrm{M}$, respectively (Figure $3 \mathrm{C}$ and Table 2 ). No binding of Oligo-7 (or any other oligo) to $A 3 \mathrm{G}_{\mathrm{CTD}}$ (or catalytic mutant) was seen by ITC $[75 \mathrm{mM}$ sodium phosphate and 75 $\mathrm{mM}$ citrate $(\mathrm{pH} 5.5)]$ due to the low DNA binding affinity for $\mathrm{A} 3 \mathrm{G}_{\mathrm{CTD}}\left[K_{\mathrm{m}}(\right.$ Oligo-3 $) \approx 600 \mu \mathrm{M}$, and $K_{\mathrm{i}}($ Oligo-7) $\approx 50 \mu \mathrm{M}]$ and low protein solubility.

To confirm the competitive nature of inhibition, the substrate concentration was varied while the inhibitor (Oligo-9) and enzyme ( $\left.\mathrm{A} 3 \mathrm{~B}_{\mathrm{CTD}}-\mathrm{QM}-\Delta \mathrm{L} 3-\mathrm{AL} 1 \mathrm{swap}\right)$ concentrations were kept constant. In the double-reciprocal plot shown in Figure 4, the lines from the least-squares fits to the data in the absence and presence of inhibitor cross the $y$-axis at essentially the same point $\left(1 / v_{\max }=71 \pm 12 \mathrm{~s} \mu \mathrm{M}^{-1}\right.$ and $1 / v_{\max }=83 \pm 32 \mathrm{~s} \mu \mathrm{M}^{-1}$, respectively). This result validates our initial prediction that $\mathrm{dZ}$ ssDNAs are competitive inhibitors of A3 enzymes.

\section{DISCUSSION}

By means of several complementary binding and activity assays, we have characterized inhibition of selected A3 variants by chemically modified ssDNAs possessing 2'-deoxyzebularine analogues. One finding was that binding of $\mathrm{dZ}$-ssDNA to inactivated proteins in which the active-site glutamic acid is replaced with alanine (Glu72 in A3A and Glu255 in $\mathrm{A}_{3} \mathrm{~B}_{\mathrm{CTD}}$ ) was significantly reduced in comparison to the substrate. This 
A)

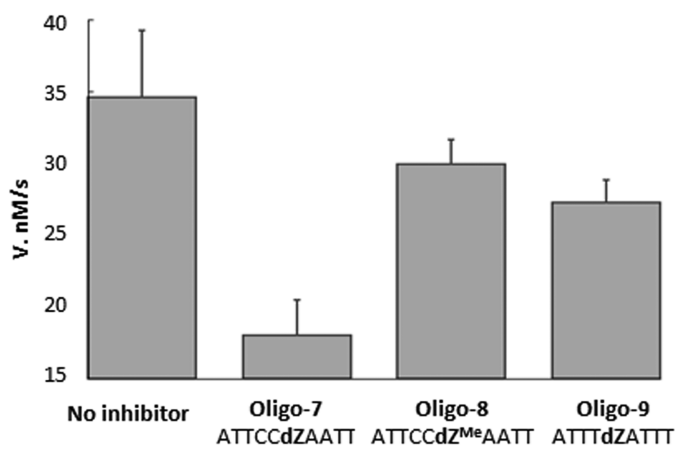

C)

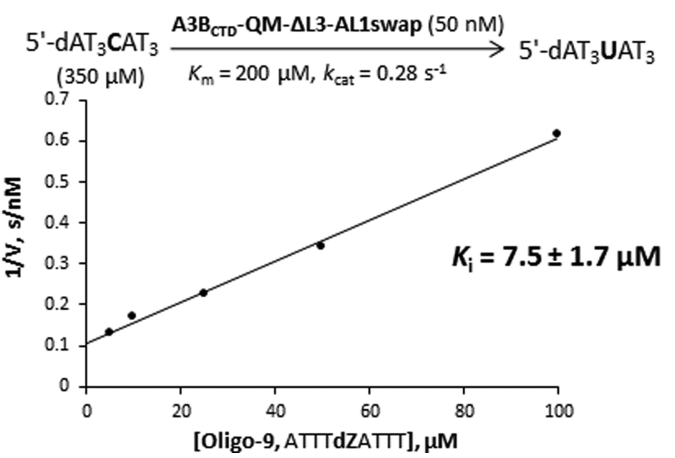

B)

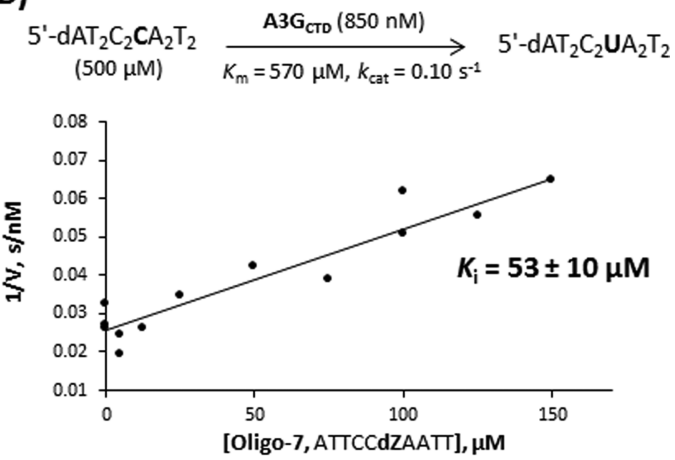

D)

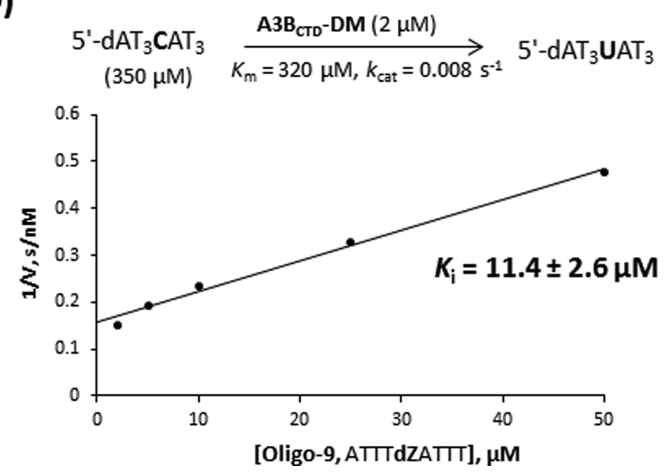

Figure 3. Inhibition of $\mathrm{A} 3$ proteins by modified oligos in the NMR deaminase assay. (A) Effects of $\mathrm{dZ}$ and $\mathrm{dZ}^{\mathrm{Me}}$-containing ssDNAs on deamination of Oligo-3 $\left(\mathrm{dAT}_{2} \mathrm{C}_{3} \mathrm{~A}_{2} \mathrm{~T}_{2}, 500 \mu \mathrm{M}\right)$ by $\mathrm{A}_{3} \mathrm{G}_{\mathrm{CTD}}(850 \mu \mathrm{M})$ at $298 \mathrm{~K}$. The speed of deamination in the absence of inhibitor (No inhibitor) and in the presence of $100 \mu \mathrm{M}$ ssDNA inhibitors (dZ-containing Oligo-7 and Oligo-9 as well as $\mathrm{dZ}^{\mathrm{Me}}$-containing Oligo-8) is shown. (B) Inhibition of $\mathrm{A}^{3 \mathrm{G}_{\mathrm{CTD}}}{ }^{-}$ catalyzed deamination of Oligo-3 by dZ-containing Oligo-7. (C) Inhibition of $A 3 B_{\text {СтD }}-Q M-\Delta L 3-A L 1$ swap-catalyzed deamination of Oligo-2 by dZcontaining Oligo-9. (D) Inhibition of $\mathrm{A}^{3} \mathrm{~B}_{\text {Стр }}$-DM-catalyzed deamination of Oligo-2 by dZ-containing Oligo-9. The bold $\mathrm{C}$ is the target $2^{\prime}$ deoxycytidine deaminated by the enzyme. In all cases, the DNA substrate and inhibitor have the same sequence except that the cytidine of the substrate has been changed to $\mathrm{dZ}$.



1/[Oligo-2, ATTTCATTT], $\mu \mathrm{M}^{-1}$
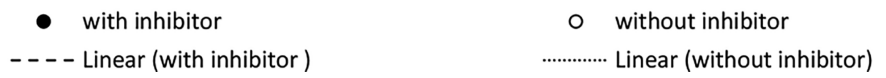

Figure 4. Double-reciprocal plot $(1 / V$ vs $1 /[\mathrm{S}])$ of deamination of the DNA substrate (Oligo-2) by A3B $\mathrm{CTD}_{\mathrm{D}} \mathrm{QM}-\Delta \mathrm{L} 3-\mathrm{AL} 1$ swap at different substrate concentrations in the absence and presence of dZ-containing Oligo-9 at $20 \mu \mathrm{M}$.

indicates that the glutamate in the active site is strongly involved in interaction with the transition state of deamination. These data are consistent with a model in which the Glu modifies the TSA by protonation of $\mathrm{N} 3$ of the nucleobase causing the addition of a water molecule to the $\mathrm{C} 4 \mathrm{of} \mathrm{dZ}$, as established for
CDA. ${ }^{54}$ In addition, our data clearly show an influence of buffer on dissociation constants, with a high ionic strength $(800 \mathrm{mM})$ depressing the affinity by more than 2 orders of magnitude relative to that with a medium ionic strength $(\sim 100 \mathrm{mM})$. Our observation that $\mathrm{dZ}^{\mathrm{Me}}$ in the structure of ssDNA did not provide 
significant inhibition of $A 3 G_{\text {CTD }}$ is consistent with earlier observations that 5-Me-cytidine was not deaminated by A $3 \mathrm{G}_{\text {СтD }} \cdot{ }^{51-53}$ On the other hand, $\mathrm{dZ}$ instead of $\mathrm{dC}$ in ssDNA produced competitive, micromolar inhibitors of $A 3 G_{C T D}$, $\mathrm{A} 3 \mathrm{~B}_{\mathrm{CTD}}-\mathrm{QM}-\Delta \mathrm{L}-\mathrm{AL}$ 1swap, and $\mathrm{A} 3 \mathrm{~B}_{\mathrm{CTD}}-\mathrm{DM}$. The fact that $\mathrm{dZ}$ and $\mathrm{dZ}^{\mathrm{Me}}$ used in the same oligo sequence had different inhibitory effects on $A 3 G_{\text {CTD }}$ under identical conditions means that structure of the TSA determines the inhibitory potential of the TSA-containing oligo. Moreover, adjacent nucleotides proximal to the TSA define the selectivity for binding and concomitant inhibition of a particular A3 family member as in the case of selective inhibition of $A 3 \mathrm{G}_{\text {СТD }}$ by Oligo-7 and not by Oligo-9 (Figure 3A). These sequence-dependent molecular recognition properties provide opportunities for the design of specific inhibitors of A3 family members.

Through high-throughput screening efforts, covalent small molecule A3G inhibitors with low micromolar potencies have been identified. ${ }^{33,55}$ To date, no small molecule A3A or A3B inhibitors have been reported. Chemically modified ssDNAs have been utilized in previous studies to understand the deamination of cytosine in the absence of structural information about the ssDNA/A3 complex. ${ }^{56}$ Here, we evaluated chemically modified ssDNAs as potential A3 inhibitors and found similar (micromolar) inhibition constants as found for small molecule A3G inhibitors. An approximately 10-30-fold decrease in the apparent inhibition constants $\left(K_{\mathrm{i}}\right)$ of $\mathrm{dZ}$ oligos over $K_{\mathrm{m}}$ of the corresponding $\mathrm{dC}$-containing substrates was observed in our study. In comparison, zebularine as an individual nucleoside shows a 100 -fold lower $K_{\mathrm{i}}$ in comparison to the $K_{\mathrm{m}}$ of cytidine for $\mathrm{CDA}^{54}$ This indicates that the preferences for TSA vary between $A 3$ and CDAs. In addition, the strength of binding of the dZ-ssDNA to the A3 enzyme may be mediated by the interactions of surrounding nucleotides with amino acids close to the active site. The latter possibility is supported by the fact that introduction of modified nucleotides at positions -2 to +1 substantially affected the rate of deamination (target $\mathrm{dC}$ has number 0 , nucleotides in the $5^{\prime}$-direction have a minus sign, and nucleotides in the $3^{\prime}$-direction have a plus sign). ${ }^{56}$ Recent work has revealed that ssDNA adopts a U-shape for the target $\mathrm{dC}$ to enter the active site of the protein, ${ }^{29,30,42}$ such that nucleotides at positions $-2,-1$, and +1 have strong interactions with the proteins, as well. Our previously published NMR-based method of small changes shows additional transient interactions with nucleotides farther from the active site. ${ }^{29}$ This also correlates with our observations that short DNA sequences (5-mers) bind much more weakly than longer ssDNAs (>9-mers) to A3AE72A (Tables 1 and 2) and with the results of other groups. $39,40,47$

The observed inhibition of A3 enzymes by dZ-ssDNAs highlights the importance of Glu 72 for A3A (Glu255 for A3B $\mathrm{B}_{\text {СТD }}$ and Glu259 for $A 3 G_{\mathrm{CTD}}$ ) in controlling substrate and dZssDNA binding. Therefore, development of A3 inhibitors based on TSAs that specifically react with the active-site water requires evaluation on active enzymes in contrast to the common practice of evaluation of binding to inactive active-site mutants.

Overall, our work shows that transition-state analogues potently inhibit selected A3 variants when incorporated into ssDNA. The inhibition of wild type A3A and full length $\mathrm{A} 3 \mathrm{~B}$ and $\mathrm{A} 3 \mathrm{G}$ is a subject of ongoing investigations. Nevertheless, our results provide a starting point to rationally create new A3 inhibitors, which have a potential to be further developed into adjuvants to be used in antiviral and anticancer treatments. Because cytidine-containing ssDNA species are not substrates for $\mathrm{CDA},{ }^{57}$ which accepts only individual nucleotides, our inhibitors for A3 enzymes will not affect primary metabolic functions of CDA. Taking advantage of different preferences of A3 for nucleotides surrounding the reactive 2 -deoxycytidine may also allow development of A3-specific inhibitors, targeting individual family members.

\section{ASSOCIATED CONTENT}

\section{S Supporting Information}

The Supporting Information is available free of charge on the ACS Publications website at DOI: 10.1021/acs.biochem.8b00858.

Experimental details about the synthesis of $\mathrm{dZ}$ - and $\mathrm{dZ} \mathrm{Me}^{\mathrm{Me}}$ modified oligos, protein expression and purification, and FP, ITC, thermal shift, and NMR-based kinetic assays; examples of the calculation of inhibition of A3 enzymes by $\mathrm{dZ}$-containing oligos; supplementary tables of thermodynamic parameters obtained from ITC data and the rationale behind the design of individual oligos; supplementary charts, including ITC data; and supplementary figures, including data of fluorescence deaminase assays on individual TSAs, representative data of the FP assay, and the sequence alignment of proteins used in this study (PDF)

\section{AUTHOR INFORMATION}

\section{Corresponding Authors}

*E-mail: e.harjes@massey.ac.nz.

*E-mail: daharki@umn.edu.

*E-mail: v.filichev@massey.ac.nz.

ORCID

Hideki Aihara: 0000-0001-7508-6230

Vyacheslav V. Filichev: 0000-0002-7383-3025

Daniel A. Harki: 0000-0001-5950-931X

Elena Harjes: 0000-0002-3643-9432

\section{Author Contributions}

${ }^{\#}$ M.V.K., F.M.B., S.H., and H.A.M.S. contributed equally to this work.

\section{Funding}

V.V.F., E.H., G.B.J., M.V.K., and S.H. are grateful for the financial support provided by Worldwide Cancer Research (Grant 16-1197), the Massey University Research Fund (MURF 2015, 7003), and the Institute of Fundamental Sciences of Massey University. This work was also supported by the National Institutes of Health (R01-GM110129 to D.A.H. and R.S.H. and R01-GM118000 to R.S.H., H.A., and D.A.H.), the University of Minnesota (UMN) Masonic Cancer Center (SPORE-Program Project planning seed grant to D.A.H., R.S.H., and H.A.), the UMN College of Biological Sciences, and the Prospect Creek Foundation (award to D.A.H. and R.S.H.). F.M.B. is a recipient of the graduate assistance Ph.D. scholarship awarded by the Institute of Fundamental Sciences, Massey University. The UMN Office of the Vice President for Research is gratefully acknowledged (Equipment Grant-in-Aid for purchase of a BioAutomation MerMade DNA synthesizer). R.S.H. is the Margaret Harvey Schering Land Grant Chair for Cancer Research, a Distinguished University McKnight Professor, and an Investigator of the Howard Hughes Medical Institute. The authors thank the International Mobility Fund from the Royal Society of New Zealand (IMF-Mau140) for sponsoring the visit of R.S.H. to Massey University to start the 
collaboration as well as Massey University Research Funding (international visitor, 2016) for sponsoring the visit of D.A.H. to Massey University to design this research.

\section{Notes}

The authors declare the following competing financial interest(s): D.A.H. and R.S.H. are co-founders, shareholders, and consultants of ApoGen Biotechnologies, Inc. H.A. is a consultant of ApoGen Biotechnologies, Inc.

\section{ACKNOWLEDGMENTS}

The authors thank M. Carpenter, K. Kurahashi, M. Li, J. McCann, A. Molan, N. Shaban, and W. Brown for mentoring and technical training during F.M.B.'s visit to the Harris and Aihara laboratories at the University of Minnesota. The authors show our gratitude to K. Kurahashi (University of Minnesota) for assistance in protein expression and purification. NMR and mass spectrometry facilities at Massey University and the assistance of Dr. P. J. B. Edwards and D. Lun are gratefully acknowledged.

\section{REFERENCES}

(1) Harris, R. S., and Dudley, J. P. (2015) APOBECs and virus restriction. Virology 479-480, 131-145.

(2) Malim, M., and Bieniasz, P. (2012) HIV restriction factors and mechanisms of evasion. Cold Spring Harbor Perspect. Med. 2, a006940.

(3) Izumi, T., Shirakawa, K., and Takaori-Kondo, A. (2008) Cytidine deaminases as a weapon against retroviruses and a new target for antiviral therapy. Mini-Rev. Med. Chem. 8, 231-238.

(4) Peretti, A., Geoghegan, E. M., Pastrana, D. V., Smola, S., Feld, P., Sauter, M., Lohse, S., Ramesh, M., Lim, E. S., Wang, D., Borgogna, C., FitzGerald, P. C., Bliskovsky, V., Starrett, G. J., Law, E. K., Harris, R. S., Killian, J. K., Zhu, J., Pineda, M., Meltzer, P. S., Boldorini, R., Gariglio, M., and Buck, C. B. (2018) Characterization of BK Polyomaviruses from Kidney Transplant Recipients Suggests a Role for APOBEC3 in Driving In-Host Virus Evolution. Cell Host Microbe 23, 628-635.e7.

(5) Vieira, V. C., Leonard, B., White, E. A., Starrett, G. J., Temiz, N. A., Lorenz, L. D., Lee, D., Soares, M. A., Lambert, P. F., Howley, P. M., and Harris, R. S. (2014) Human Papillomavirus E6 Triggers Upregulation of the Antiviral and Cancer Genomic DNA Deaminase APOBEC3B. $m$ Bio 5, e02234-02214.

(6) Verhalen, B., Starrett, G. J., Harris, R. S., and Jiang, M. (2016) Functional Upregulation of the DNA Cytosine Deaminase APOBEC3B by Polyomaviruses. J. Virol. 90, 6379-6386.

(7) Kim, E.-Y., Lorenzo-Redondo, R., Little, S. J., Chung, Y.-S., Phalora, P. K., Maljkovic Berry, I., Archer, J., Penugonda, S., Fischer, W., Richman, D. D., Bhattacharya, T., Malim, M. H., and Wolinsky, S. M. (2014) Human APOBEC3 Induced Mutation of Human Immunodeficiency Virus Type-1 Contributes to Adaptation and Evolution in Natural Infection. PLoS Pathog. 10, No. e1004281.

(8) Wood, N., Bhattacharya, T., Keele, B. F., Giorgi, E., Liu, M., Gaschen, B., Daniels, M., Ferrari, G., Haynes, B. F., McMichael, A., Shaw, G. M., Hahn, B. H., Korber, B., and Seoighe, C. (2009) HIV evolution in early infection: selection pressures, patterns of insertion and deletion, and the impact of APOBEC. PLoS Pathog. 5, No. e1000414.

(9) Tsibris, A. M., Korber, B., Arnaout, R., Russ, C., Lo, C. C., Leitner, T., Gaschen, B., Theiler, J., Paredes, R., Su, Z., Hughes, M. D., Gulick, R. M., Greaves, W., Coakley, E., Flexner, C., Nusbaum, C., and Kuritzkes, D. R. (2009) Quantitative deep sequencing reveals dynamic HIV-1 escape and large population shifts during CCR5 antagonist therapy in vivo. PLoS One 4, No. e5683.

(10) Kohli, R. M., Maul, R. W., Guminski, A. F., McClure, R. L., Gajula, K. S., Saribasak, H., McMahon, M. A., Siliciano, R. F., Gearhart, P. J., and Stivers, J. T. (2010) Local sequence targeting in the AID/ APOBEC family differentially impacts retroviral restriction and antibody diversification. J. Biol. Chem. 285, 40956-40964.
(11) Rathore, A., Carpenter, M. A., Demir, O., Ikeda, T., Li, M., Shaban, N. M., Law, E. K., Anokhin, D., Brown, W. L., Amaro, R. E., and Harris, R. S. (2013) The local dinucleotide preference of APOBEC3G can be altered from $5^{\prime}$-CC to $5^{\prime}$-TC by a single amino acid substitution. J. Mol. Biol. 425, 4442-4454.

(12) Carpenter, M. A., Rajagurubandara, E., Wijesinghe, P., and Bhagwat, A. S. (2010) Determinants of sequence-specificity within human AID and APOBEC3G. DNA Repair 9, 579-587.

(13) Stenglein, M., Burns, M., Li, M., Lengyel, J., and Harris, R. (2010) APOBEC3 proteins mediate the clearance of foreign DNA from human cells. Nat. Struct. Mol. Biol. 17, 222-229.

(14) Kohli, R. M., Abrams, S. R., Gajula, K. S., Maul, R. W., Gearhart, P. J., and Stivers, J. T. (2009) A portable hot spot recognition loop transfers sequence preferences from APOBEC family members to activation-induced cytidine deaminase. J. Biol. Chem. 284, 2289822904.

(15) Venkatesan, S., Rosenthal, R., Kanu, N., McGranahan, N., Bartek, J., Quezada, S. A., Hare, J., Harris, R. S., and Swanton, C. (2018) Perspective: APOBEC mutagenesis in drug resistance and immune escape in HIV and cancer evolution. Ann. Oncol 29, 563-572.

(16) Zou, J., Wang, C., Ma, X., Wang, E., and Peng, G. (2017) APOBEC3B, a molecular driver of mutagenesis in human cancers. Cell Biosci. 7, 29.

(17) Vlachostergios, P. J., and Faltas, B. M. (2018) Treatment resistance in urothelial carcinoma: an evolutionary perspective. Nat. Rev. Clin. Oncol. 15, 495-509.

(18) Galluzzi, L., and Vitale, I. (2017) Driving to Cancer on a FourLane Expressway. Trends Genet. 33, 491-492.

(19) Sieuwerts, A. M., Willis, S., Burns, M. B., Look, M. P., Gelder, M. E. M.-V., Schlicker, A., Heideman, M. R., Jacobs, H., Wessels, L., Leyland-Jones, B., Gray, K. P., Foekens, J. A., Harris, R. S., and Martens, J. W.M. (2014) Elevated APOBEC3B Correlates with Poor Outcomes for Estrogen-Receptor-Positive Breast Cancers. Horm. Cancer 5, 405413.

(20) Law, E. K., Sieuwerts, A. M., LaPara, K., Leonard, B., Starrett, G. J., Molan, A. M., Temiz, N. A., Vogel, R. I., Meijer-van Gelder, M. E., Sweep, F. C., Span, P. N., Foekens, J. A., Martens, J. W., Yee, D., and Harris, R. S. (2016) The DNA cytosine deaminase APOBEC3B promotes tamoxifen resistance in ER-positive breast cancer. Sci. Adv. 2, No. e1601737.

(21) Olson, M. E., Harris, R. S., and Harki, D. A. (2018) APOBEC Enzymes as Targets for Virus and Cancer Therapy. Cell Chem. Biol. 25, 36-49.

(22) Ko, T. P., Lin, J. J., Hu, C. Y., Hsu, Y. H., Wang, A. H., and Liaw, S. H. (2003) Crystal structure of yeast cytosine deaminase. Insights into enzyme mechanism and evolution. J. Biol. Chem. 278, 19111-19117.

(23) Xiang, S., Short, S. A., Wolfenden, R., and Carter, C. W. (1995) Transition-state selectivity for a single hydroxyl group during catalysis by cytidine deaminase. Biochemistry 34, 4516-4523.

(24) Chung, S. J., Fromme, J. C., and Verdine, G. L. (2005) Structure of human cytidine deaminase bound to a potent inhibitor. J. Med. Chem. $48,658-660$.

(25) Betts, L., Xiang, S., Short, S. A., Wolfenden, R., and Carter, C. W., Jr. (1994) Cytidine deaminase. The 2.3 A crystal structure of an enzyme: transition-state analog complex. J. Mol. Biol. 235, 635-656.

(26) Teh, A.-H., Kimura, M., Yamamoto, M., Tanaka, N., Yamaguchi, I., and Kumasaka, T. (2006) The 1.48 Å Resolution Crystal Structure of the Homotetrameric Cytidine Deaminase from Mouse. Biochemistry 45, $7825-7833$.

(27) Johansson, E., Mejlhede, N., Neuhard, J., and Larsen, S. (2002) Crystal Structure of the Tetrameric Cytidine Deaminase from Bacillus subtilis at $2.0 \AA$ Resolution. Biochemistry 41, 2563-2570.

(28) Xiang, S., Short, S. A., Wolfenden, R., and Carter, C. W., Jr. (1996) Cytidine deaminase complexed to 3-deazacytidine: a "valence buffer" in zinc enzyme catalysis. Biochemistry 35, 1335-1341.

(29) Harjes, S., Jameson, G. B., Filichev, V. V., Edwards, P. J. B., and Harjes, E. (2017) NMR-based method of small changes reveals how DNA mutator APOBEC3A interacts with its single-stranded DNA substrate. Nucleic Acids Res. 45, 5602-5613. 
(30) Shi, K., Carpenter, M. A., Banerjee, S., Shaban, N. M., Kurahashi, K., Salamango, D. J., McCann, J. L., Starrett, G. J., Duffy, J. V., Demir, O., Amaro, R. E., Harki, D. A., Harris, R. S., and Aihara, H. (2017) Structural basis for targeted DNA cytosine deamination and mutagenesis by APOBEC3A and APOBEC3B. Nat. Struct. Mol. Biol. 24, $131-139$.

(31) Shi, K., Carpenter, M. A., Kurahashi, K., Harris, R. S., and Aihara, H. (2015) Crystal Structure of the DNA Deaminase APOBEC3B Catalytic Domain. J. Biol. Chem. 290, 28120-28130.

(32) Harjes, S., Solomon, W. C., Li, M., Chen, K. M., Harjes, E., Harris, R. S., and Matsuo, H. (2013) Impact of H216 on the DNA binding and catalytic activities of the HIV restriction factor APOBEC3G. J. Virol 87, 7008-7014.

(33) Li, M., Shandilya, S., Carpenter, M., Rathore, A., Brown, W., Perkins, A., Harki, D., Solberg, J., Hook, D., Pandey, K., Parniak, M., Johnson, J., Krogan, N., Somasundaran, M., Ali, A., Schiffer, C., and Harris, R. (2012) First-in-class small molecule inhibitors of the singlestrand DNA cytosine deaminase APOBEC3G. ACS Chem. Biol. 7, 506517.

(34) Burns, M. B., Lackey, L., Carpenter, M. A., Rathore, A., Land, A. M., Leonard, B., Refsland, E. W., Kotandeniya, D., Tretyakova, N., Nikas, J. B., Yee, D., Temiz, N. A., Donohue, D. E., McDougle, R. M., Brown, W. L., Law, E. K., and Harris, R. S. (2013) APOBEC3B is an enzymatic source of mutation in breast cancer. Nature 494, 366-370.

(35) Leonard, B., McCann, J. L., Starrett, G. J., Kosyakovsky, L., Luengas, E. M., Molan, A. M., Burns, M. B., McDougle, R. M., Parker, P. J., Brown, W. L., and Harris, R. S. (2015) The PKC/NF-kappaB signaling pathway induces APOBEC $3 \mathrm{~B}$ expression in multiple human cancers. Cancer Res. 75, 4538-4547.

(36) Byeon, I. J., Byeon, C. H., Wu, T., Mitra, M., Singer, D., Levin, J. G., and Gronenborn, A. M. (2016) Nuclear Magnetic Resonance Structure of the APOBEC3B Catalytic Domain: Structural Basis for Substrate Binding and DNA Deaminase Activity. Biochemistry 55, 2944-2959.

(37) Barchi, J. J., Haces, A., Marquez, V. E., and McCormack, J. J. (1992) Inhibition of Cytidine Deaminase by Derivatives of 1- $(\beta$-DRibofuranosyl)-Dihydropyrimidin-2-One (Zebularine). Nucleosides Nucleotides 11, 1781-1793.

(38) Vives, M., Eritja, R., Tauler, R., Marquez, V. E., and Gargallo, R. (2004) Synthesis, stability, and protonation studies of a selfcomplementary dodecamer containing the modified nucleoside 2'deoxyzebularine. Biopolymers 73, 27-43.

(39) Chelico, L., Pham, P., Calabrese, P., and Goodman, M. F. (2006) APOBEC3G DNA deaminase acts processively $3^{\prime} \rightarrow 5^{\prime}$ on singlestranded DNA. Nat. Struct. Mol. Biol. 13, 392-399.

(40) Byeon, I. J., Ahn, J., Mitra, M., Byeon, C. H., Hercik, K., Hritz, J., Charlton, L. M., Levin, J. G., and Gronenborn, A. M. (2013) NMR structure of human restriction factor APOBEC3A reveals substrate binding and enzyme specificity. Nat. Commun. 4, 1890.

(41) Altermatt, R., and Tamm, C. (1985) Nucleoside und Nucleotide. Teil 22. Synthese eines Tridecanucleosiddodecaphosphats, das die unnatürliche Base 2(1H)-Pyrimidinon enthält. Helv. Chim. Acta 68, $475-483$.

(42) Kouno, T., Silvas, T. V., Hilbert, B. J., Shandilya, S. M. D., Bohn, M. F., Kelch, B. A., Royer, W. E., Somasundaran, M., Kurt Yilmaz, N., Matsuo, H., and Schiffer, C. A. (2017) Crystal structure of APOBEC3A bound to single-stranded DNA reveals structural basis for cytidine deamination and specificity. Nat. Commun. 8, 15024.

(43) Rossi, A. M., and Taylor, C. W. (2011) Analysis of protein-ligand interactions by fluorescence polarization. Nat. Protoc. 6, 365-387.

(44) Auld, D. S., Farmen, M. W., Kahl, S. D., Kriauciunas, A., McKnight, K. L., Montrose, C., and Weidner, J. R. (2012) Receptor Binding Assays for HTS and Drug Discovery. In Assay Guidance Manual [Internet], Eli Lilly \& Co. and National Center for Advancing Translational Sciences, Bethesda, MD.

(45) Kenakin, T. P. (1993) Pharmacologic Analysis of Drug-Receptor Interaction, 2nd ed., Raven, New York.

(46) Bohn, M.-F., Shandilya, S. M. D., Silvas, T. V., Nalivaika, E. A., Kouno, T., Kelch, B. A., Ryder, S. P., Kurt-Yilmaz, N., Somasundaran,
M., and Schiffer, C. A. (2015) The ssDNA Mutator APOBEC3A Is Regulated by Cooperative Dimerization. Structure 23, 903-911.

(47) Silvas, T. V., Hou, S., Myint, W., Nalivaika, E., Somasundaran, M., Kelch, B. A., Matsuo, H., Kurt Yilmaz, N., and Schiffer, C. A. (2018) Substrate sequence selectivity of APOBEC3A implicates intra-DNA interactions. Sci. Rep. 8, 7511.

(48) Furukawa, A., Nagata, T., Matsugami, A., Habu, Y., Sugiyama, R., Hayashi, F., Kobayashi, N., Yokoyama, S., Takaku, H., and Katahira, M. (2009) Structure, interaction and real-time monitoring of the enzymatic reaction of wild-type APOBEC3G. EMBO J. 28, 440-451.

(49) Turnbull, W. B., and Daranas, A. H. (2003) On the value of c: can low affinity systems be studied by isothermal titration calorimetry? J. Am. Chem. Soc. 125, 14859-14866.

(50) Cimmperman, P., and Matulis, D. (2011) Protein Thermal Denaturation Measurements via a Fluorescent Dye. In Biophysical Approaches Determining Ligand Binding to Biomolecular Targets: Detection, Measurement and Modelling, Chapter 8, pp 247-274, The Royal Society of Chemistry, Cambridge, U.K.

(51) Carpenter, M. A., Li, M., Rathore, A., Lackey, L., Law, E. K., Land, A. M., Leonard, B., Shandilya, S. M., Bohn, M. F., Schiffer, C. A., Brown, W. L., and Harris, R. S. (2012) Methylcytosine and normal cytosine deamination by the foreign DNA restriction enzyme APOBEC3A. $J$. Biol. Chem. 287, 34801-34808.

(52) Schutsky, E. K., Nabel, C. S., Davis, A. K. F., DeNizio, J. E., and Kohli, R. M. (2017) APOBEC3A efficiently deaminates methylated, but not TET-oxidized, cytosine bases in DNA. Nucleic Acids Res. 45, $7655-7665$.

(53) Ito, F., Fu, Y., Kao, S. A., Yang, H., and Chen, X. S. (2017) FamilyWide Comparative Analysis of Cytidine and Methylcytidine Deamination by Eleven Human APOBEC Proteins. J. Mol. Biol. 429, 17871799.

(54) Frick, L., Yang, C., Marquez, V. E., and Wolfenden, R. V. (1989) Binding of pyrimidin-2-one ribonucleoside by cytidine deaminase as the transition-state analog 3,4-dihydrouridine and contribution of the 4-hydroxyl group to its binding affinity. Biochemistry 28, 9423-9430.

(55) Olson, M. E., Li, M., Harris, R. S., and Harki, D. A. (2013) Smallmolecule APOBEC3G DNA cytosine deaminase inhibitors based on a 4-amino-1,2,4-triazole-3-thiol scaffold. ChemMedChem 8, 112-117.

(56) Rausch, J. W., Chelico, L., Goodman, M. F., and Le Grice, S. F. (2009) Dissecting APOBEC3G substrate specificity by nucleoside analog interference. J. Biol. Chem. 284, 7047-7058.

(57) Yoo, C. B., Jeong, S., Egger, G., Liang, G., Phiasivongsa, P., Tang, C., Redkar, S., and Jones, P. A. (2007) Delivery of 5-aza-2'deoxycytidine to cells using oligodeoxynucleotides. Cancer Res. 67, $6400-6408$. 